\title{
Issues and Principles on Non-Navigational Use of International Watercourses
}

\author{
SaAD AbBas KadHim AlsaAdi \\ RASYIKAH MD. KHALID \\ Wan Siti Adibah Wan Dahalan
}

\begin{abstract}
The concept of international watercourse has been used in many international conventions referring to a river and its tributaries and related canals crossing two or more countries. The notable ones include the Mekong River which crosses five states in the East Asia region and the Danube and Rhine rivers which cross 12 states in Europe. This article addresses relevant international principle which will justify the claims and counter-claims on non-navigational use of international watercourses. It justifies the conflicting parties' demands on shared watercourses. Accordingly, this paper adopts the qualitative doctrinal analysis of the principle of reasonable and equitable utilization under the United Nations Convention on the International Watercourses (UNWC) 1997. Relevant provision will be analysed and harnessed in addressing the respective conflict and weighing each argument of the conflicting parties. It is hoped that the utilisation of the available legal recourses will help strengthen the exisitng legal framework in solving conflict over non-navigational use of international watercourses.
\end{abstract}

Keywords: International rivers; UNWC; reasonable and equitable utilization

\section{INTRODUCTION}

The United Nation (UN) started concentrating on international rivers issues in late 1950s. This happens when states failed to develop a shared freshwater resources agreement despite a growing recognition of customary international law in governing international watercourses. In 1959, the UN General Assembly (UNGA) adopted resolution 1401 which requested the Secretary-General to submit a report on member states's legislations, existing bilateral and multilateral treaties, tribunal decisions and arbitral awards; or studies conducted by non-governmental organizations on the non-navigational use of international watercourses. In 1963, UNGA submitted a report in 1963 entitled "Legal Problems Relating to the Utilizing and Use of International Rivers" and formed a working group in 1966 to elaborate a framework convention on the law of the non-navigational uses of international watercourses. Following this, the International Law Commission (ILC) incorporated the law on non-navigational uses of international watercourses in its 23rd session in 1971, according to the recommendation of UNGA resolution 2669 (1970). This was followed by the 1977 UN Water Conference in Mar del Plata, Argentina where the international community urged the ILC to work on the non-navigational uses of international watercourses. In 1994, the ILC produced the final
Draft Articles of "the law on non-navigational uses of international watercourses" with a resolution on transboundary-confined water. The ILC recommended that UNGA must call for an international conference to conclude the proposed convention based on the prepared Draft Articles. The United Nations Convention on the International Watercourses (UNWC) was concluded on 21st May 1997 and was annexed to the UNGA Resolution 229 (1997). It consists of 37 articles on general principles, planned measures, protection, preservation and management, harmful condition and emergency situation. An annex to the Convention sets forth procedures to be followed in the event where states have agreed to submit a dispute to arbitration. The UNWC was adopted following the vote of 103 in favor, 3 against and 27 abstentions. This is the historical development towards promulgating the UNWC. This paper will elaborate in the scope of UNWC and analyse one important principle in the UNWC, which is the principle of reasonable and reeasonable utilization of international watercourses.

\section{THE UNITED NATIONS CONVENTION ON THE INTERNATIONAL WATERCOURSES (UNWC) 1997}

The UNWC represents the most reliable and useful instrument in non-navigational use of international 
watercourses. Salman (2007) argues that UNWC will continue to be the most authoritative instrument in the field of international water law for ongoing contention and future conflict as the demand for water resource increases. Similarly, Alistair Rieu-Clarke et al. (2012) states that the UNWC is a codification of customary law and provides the legal framework for sustainable management of transboundary waters. They argue that the UNWC identifies the legal rights and obligations on water use, ensures integrity of the regime through monitoring and assessment of dispute settlement, and facilitates the modifications of the existing regime to adapt to the changing needs and circumstances.

The UNWC sets out useful general rules for future negotiations between co-riparians in concluding their agreements. It encourages states to apply its general principles in their agreements even after their departure from the UNWC (Soboka, 2008). Scholars, including McCaffrey (1997) and Tanzi (1997) believe that the UNWC framework predict that watercourse problems can be addressed in an integrated and coordinated approach throughout consultation and negotiation. In contrast, Lema (2015) thinks that leaving everything to be solved by negotiations could lead to infinite dialogue as water resources are becoming scarce in many basins, while the UNWC provides no clear guidelines for negotiation. This is because practical water sharing agreements can only be achieved through an in-depth assessment of water issues based on scope, substantive rules, procedural rules, dispute settlement mechanisms and institutional mechanisms (Okonkwo, 2016). Be that as it may, it is a flexible global framework instrument which can be followed by all concerned parties regardless of their geographical location or level of development.

\section{SCOPE OF THE CONVENTION}

The UNWC deals with all non-navigational uses on an international watercourse. Article 1(2) of UNWC illustrates clearly that it does not deal with the navigational uses of watercourses which have its own legal framework after World War I under the Treaty of Versailles. At this point, the impacts of navigation on other uses must be addressed in the UNWC due to the integrated relation between navigational and non-navigational uses of the watercourses and their adverse effects to water projects and pollution (Salman, 2015). Article 10(1) confirms that "in the absence of agreement or custom to the contrary, no use of an international watercourse enjoys inherent priority over other uses" even for vital human needs.

The UNWC intended to avoid the application of its rules to fishing right, unless such right have visible impacts on other uses (Alistair Rieu-Clarke, 2012). This was well drafted in Article 20, which is banning of fishing when it has impacts on obligation of protection and preservation ecosystems. Therefore, fishing and pollution from vessels adverse environmental effects fall under substantive norms of Article 27 of the UNWC. The UNWC does not mention specific uses, but it covers all uses those might have an impact on the management, protection and preservation of international watercourses. However, with the expansive definition that would be reflexive and designed to cover multiple environmental, economic and social uses of water. Article 1(1) states that the UNWC "applies to uses of international watercourses and of their waters for purposes other than navigation and to measures of protection, preservation and management related to the uses of those watercourses and their waters."

It is apparent that the ILC wishes to put an end to the question that has been raised many times, whether the expression "international watercourse" in Article 1(1) refers to the canal itself or covers the waters contained in that canal. Thus the ILC added the phrase "international watercourses and of their waters" to remove any doubt in this context. By emphasizing that this convention applies to the waters diverted from the watercourse, it refers to the actual contained waters in the watercourse.

Article 2(a) UNWC defines the term 'watercourse' as "a system of surface waters and groundwaters constituting by virtue of their physical relationship a unitary whole and normally flowing into a common terminus". The ILC defines 'groundwaters' as "the hydrological system composed a number of different components through which water flows, both on and under the surface of the land, these components include rivers, lakes, aquifers, glaciers, reservoirs and channels." Yet, "watercourse" does not include confined groundwaters, although some of the ILC members have emphasized that groundwater ought to be included in the definition of "watercourse". The ILC also considered the suggestion to study confined groundwaters as a separate issue and prepared a separate draft articles on this field. 
Groundwater form the vital part of the watercourses and the UNWC includes within the river system if it is connected hydrologically to a system of surface waters. McCaffrey (1997) clarifies that this position does not include transboundary aquifers, but may be located in a state territory with transboundary surface water. The former Special Rapporteur on the Convention's draft explained that confined aquifers ought to be governed by equal rules with those international watercourses (Mechlem, 2009). In fact, the ILC has adopted a resolution on Confined Transboundary Groundwater admitting the need to make more efforts to formulate specific rules on the Confined Transboundary Groundwaters. In 2011, the ILC has adopted the Articles on the Law of Transboundary Aquifers in its 16th Session in 2008, and adopted by UNGA at its 63rd Session in the same year.

Under the UNWC, the 'watercourse' concept include the system of surface and groundwater that flow normally into a common terminus. This aims to reach a compromise between two views in this line. The first view insisted that the phrase of "common terminus" should be deleted due to hydrological error. The second conquered with "common terminus" as it limits the geographical scope. For instance, the fact that two different drainage basins were connected by a channel would not make them part of a single watercourse. The ILC explains that the Danube and the Rhine do not represent a one basin "single system" as they meet certain times of the year, despite that water flows from the Danube as a groundwater into the Rhine by Lake Constance (Alistair Rieu-Clarke et al., 2012). Thus, when two different basins altered and connected by a canal, this would not make them part of a single watercourse.

The UNWC clarifies the 'international' watercourse in its Article 2(b) to mean "a watercourse, parts of which are situated in different states" while the word "situated" indicates that the water in motion and not static like canals, lakes bed and aquifer. Thus the meaning of a watercourse may depend on its geographical characteristics. The concept of "international watercourses" also applies to watercourses systems that cross international boundaries, whether major or minor watercourses and their tributaries, connected lakes and groundwater. Daming He et al. (2017) argue that "rivers that cross or from national boundaries are collectively called international rivers. Some of international rivers that flow through two or more states are called transnational, transboundary or multinational rivers, while some international rivers or lakes separating two or more states are called Boundary Rivers. This correspond with Article 1(1) Helsinki Convention which defines transboundary waters as "any surface or ground waters, which mark, cross or are located on boundaries between two or more states" regardless if it flows to the sea or end at a straight line across their respective mouths between points on the low-water line of their banks.

On a similar note, Article 1 of the Sino-Kazakh Agreement defines transboundary waters as "all rivers/river flows that cross state borders or are located along the border." The rules are different if the watercourse changes its routes by an accretion and erosion. In that case, it is almost agreed that the territorial frontiers of a state will change following with the new rivers' way. However, if the change happens by avulsion due to the human intervention, in which the situation in the general rules of the boundary must remain imposed to keep the original location of the river (Donaldson, 2011).

Under Article. 2(c) UNWC, "watercourse state" refers either a state that shares an international watercourse with other states, or a regional economic integration organization, which includes at least one-member state sharing a watercourse with other states. Nevertheless, in practice, the priority of legal relationship has been given to the states parties that share the same international watercourse (Tanzi, 1997). The terms "other states" may also include two groups. First, non-contracting riparian states located on an international watercourse. For instance, Article 23 requires the watercourse states to protect the marine environment of "other states" while Article 28 refers to emergency to watercourse states or other states including earthquakes, landslides, floods and industrial accidents that would impact international watercourses. In this regard, customary law codified by the UNWC will still be applicable to non-contracting states. The second meaning of "other states" relates to contracting non-riparian states which may not have any rights to use or develop an international watercourse, but their signing to the convention has strengthened the international law rules in this field (Alistair Rieu-Clarke et al. 2012).

Prior to the UNWC, many states have solved their dispute over transboudary waters through agreements. Hence, they have examined the UNWC 
thoroughly to avoid inconsistencies during the UN General Assembly 12th Working Group. The Portuguese, Finnish and French has avoided using the convention as reference or a supplement to their bilateral agreements. Zambia pointed out that the UNWC would not impact the existing agreements on shared watercourse in the Southern African Development Community, which had been drafted based on the ILC Draft Articles. In contrast, Czech Republic will use the UNWC as a supplementary and progressive development of international law rather than a codification process. Canada suggested adding of "except as may be provided otherwise by convention, agreement or binding custom among the watercourse states" to the end of Article 1(1) to reflect the formation of Article 1 of the Helsinki Rules on the Uses of the Waters of International Rivers of 1966. Netherlands supported the Mexican position that the UNWC must be adopted in negotiating new international watercourse agreements.

Although many states prefer using bilateral agreements to govern their international rivers, there are over 263 international watercourses and untold number of transboundary aquifers which may cause dispute in the future (Zawahri, 2011). These international watercourses generate around $60 \%$ of the world freshwater crossing 145 state and home to about $40 \%$ of the world's population. Thus, there is a crucial need to find a legal framework to govern these contested resources. States must have a mutual or basic understandings to support fair legal rules in this context, as gaps or failings in watercourse conventions could pose serious barriers to cooperation (Loures et al., 2015).

Article 3(4) of UNWC requires states parties when concluding an agreement on international watercourse to "define the waters to which it applies" due to three reasons: a. to confirm unquestioned watercourse states to determine the scope of their agreement; $b$. to let other respective states notice on the exact subject of the agreement; c. to facilitate the international watercourse negotiations whether localized or general. Still, there is an additional barrier to expand state parties of the UNWC. Article 4 indicates that the UNWC does not affect the obligations and rights of watercourse states deriving from the agreement that are in force, but the parties, where applicable, need to harmonize these agreements with the basic principles of the UNWC. In the same way, some states have not shown an interest to be parties due to confusion in defining the watercourse state under Article 2(c), and why include regional economic integration organizations in Article 2(d). These organizations are not states and this kind of articulation is difficult to follow by a sovereign state.

These hesitations did not prohibit the UNWC to impact and gain considerable outcomes on multilateral and bilateral water conventions (Salman, 2015). It has been acknowledged by the ICJ in the Gabcikovo-Nagymaros Project (Hungary/ Slovakia), Judgment, I. C. J. Reports 1997, and the Southern African Development Community member states had revised their Protocol of 1995 about sharing watercourse systems in 2000 to suit the UNWC. Similarly, the environmental, management, installations and regulations provisions of the UNWC were considered in the Protocol for Sustainable Development of Lake Victoria Basin in 2003.

The ILC allows state parties to apply the convention rules or adjust them to be compatible with the special characteristic of their watercourse or part thereof. However, it must be consulted with the concerned states in good faith. This view has adopted by the arbitral award on the Lake Lanoux case, whereby France and Spain had been holding lengthy consultations and negotiations from 1917 until 1956. Likewise, Article 3(4) UNWC protects the rights of non-contracting riparian states when dealing with the watercourse as a whole, and recognizing that subsystem agreements are needed in some international watercourses such as the Indus, the Plate and the Niger rivers. Besides, there are numerous agreements that followed the same approach including the Convention for Protection of the Rhine against Chemical Pollution 1976.

Article 4 has considered equal right among the riparian states within the UNWC. When an agreement addresses the watercourse as a whole, then it should include all related parties as there are wide-basin agreement impacts despite of their varied interest. If a watercourse state is affected significantly by an agreement implemented on part of the watercourse, that state should become a party to that agreement. The ILC insisted that the third party state should get an opportunity to join in consultations and negotiations with those who could consider a proposed plan and who would substantially reduce the amount of water that flow within the territory of that state.

This view was supported by judge Hudson as it aligns with his opinion in the case of the diversion of water from the Muse case between 
Netherlands and Belgium (PCIJ Reports, Serious $\mathrm{A} / \mathrm{B}$, No. 70, 1937). If not for the independence of Article 38 Statute of the ICJ, the court would have gained freedom to consider the principle of equity as part of the international law. For instance, two basin states with a convention in force; the framework convention would likely to have a vital influence to the consultations and negotiations on the subsequent water agreements between them. In the transboundary water cooperation of the Aral Sea Basin, there are several bilateral, regional and international level without consideration of the integration between each other and articulated them in line with the principles of international water law (Alistair Rieu-Clarke et al. 2012).

\section{THE PRINCIPLE OF REASONABLE AND EQUITABLE UTILIZATION}

The principle of reasonable and equitable utilization becomes famous after it has been philosophically adopted by the American Supreme Court in the Delaware River case between the states of New Jersey and New York. The court stated that a river is more than an amenity it is treasure as it offers necessity of life, and since the Delaware River passes through more than one state territory, it must be rationed to those who have power over it. This decision was based on the concept of sovereign equality of independent states rather than of a quasi-sovereign units in a federal states (McCaffrey 1997).

The principle of equitable utilization is a basic principle of international water law adopted by the Helsinki Rules. It has two functions; the first is drawing the objective to be achieved by applying equitable and reasonable use. The second is addressing a vital operational function at the process level by requesting all relevant parties to consider all factors and circumstances to balance the needs and proposal used by riparian states (Alistair Rieu-Clarke et al. 2012). It is incorporated in Article $5 \mathrm{UNWC}$ as it is a holistic principle for water allocation and protection. The principle is dynamic and crucial for active cooperation of riparian states and is the cornerstone of international law related to international watercourses.

The notion of equality of right enshrined in the Article 1(2) of the UN Charter represents the essential starting point in the international order, since it does not give any state an inherent superior claim over the use of international watercourse. However, there are difficulties in relating this principle to other concepts in the UNWC such as sustainable or optimal since those concepts are intentionally vague for political and legal motives (Aaron Wolf, 1998). Perhaps, Caponera (1993) is right when describing this principle by saying:

A state has an equal right to that of another state in sharing the utilization of the shared international watercourses. Since each riparian state cannot satisfy its needs concerning international watercourses to their full extent, some adjustment or accommodation is necessary.

The interpretation of this principles by upstream states can be summed up in Dr. Amnat Wongbandit's comments on Thailand's law; that water is a public domain and anybody can have free access to water according to the Civil and Commercial Code. This interpretation allows upstream states to exploit the river content as much as they can to meet their reasonable need. Turkey supports this interpretation and stated at the meeting of the Working Group of the UNWC Draft that:

The regulation of international watercourses had acquired vital importance in relations between states particularly in the regions where water resources were scarce. Its approach [Turkey] was based on the belief that, since water is a finite commodity, the utilization of international watercourses should be tied to common understandings and principles. Provisions which were too specific and detailed should therefore be avoided.

This interpretation has given the UNWC many challenges from both the upstream and downstream states. Salman (2015) holds that the upstream states still consider the convention as biased in favour of the lower riparian states since it is separately and specifically addressing the obligation not to cause harm. That is why China, Burundi and Turkey voted against the adoption of the UNWC. Other countries which abstained are also upper riparian states including Ethiopia, Mali, Tanzania and Bolivia. On the contrary, many downstream states like Egypt, Peru, France and Pakistan thought this convention favors upstream states since it subordinates the no-harm principle within the concept of equitable and reasonable utilization. China has initially supported the Draft Articles of UNWC as it represented a realistic balanced approach to reconcile the different interests of watercourse states, but later voted against it. 
Stephen Schwebel (1982) the former Special Rapporteur of the ILC Commission on UNWC stated that "the right of each state to share equitably in the uses of the waters of international watercourse systems is undisputable". In 1981, he mentioned in his Third Report the initial set of the drafted Articles on the law of non- navigational uses of international watercourses. This draft does not include the principle of reasonable utilization with the term of "reasonable" to describe the utilization of the international watercourses. He excluded reasonable use since it was the basis of the USA argument in its dispute with Canada on the Kootenay River.

The ILC noted that there is a need to distinct between "reasonable" and "equitable". Reasonable is applied in the judgment on the quality of the use, while equitable performance in balancing process of the different uses between states in case of conflict of use (Alistair Rieu-Clarke et al. 2012). Hence, equitable utilization refers to equitable apportionment, which could mean sharing water among states or representing the actual applicability of the principle of sovereign equality of states to share of the watercourse based on principles of equity (Vick 2012). It could find its roots in the reasonable use of shared waters under the common law on private right or riparian rights.

McCaffrey (1997) argues that equality of right does not mean an entitlement to an equal share. However, it must be supported due to the complexity in attaining an equitable allocation of shared water resources based on the hydrological, ecological and integrity of the watercourse system. Utton (1996) thought that the principle of equitable and reasonable utilization finds a compromise between the absolute territorial integrity doctrine insistence of downstream states and the absolute territorial sovereignty doctrine affirmation of upstream states. Tanzi (1997) states that the principle implies a fair balance of uses as between states sharing a watercourse.

The principle of equitable utilization is based on the notion of equality of right which has been recognized in 1929 by the PCIJ in the River Oder Case. The notion has also been supported by the ICJ in the case of the Gabcikovo-Nagymaros Project between Hungary and Slovakia (ICJ Reports 1997). The ICJ has supported the principle of equitable and reasonable utilization through its decision in that case by ruling out that the unilateral acts of Slovakia to use around 80-90\% of the waters of the Danube waters, was a violence to Hungary's basic right to an equitable and reasonable sharing of the resources of an international watercourse. That decision was issued after the adoption of UNWC and the principle acquired the status of customary international law (Jolly, 2018). The case of Pulp Mills between Argentina v Uruguay in 2006 further proves the close relationship between the notion of sustainable development and equitable sharing of resources.

The ICJ confirms that equity is part of the rules on international watercourses in the case of Continental Shelf Tunisia $v$ Libya (ICJ Reports 1982) whereby:

Equity as a legal concept is a direct emanation of the idea of justice ... In the course of the history of legal systems, the term 'equity' has been used to define various legal concepts. It was often contrasted with the rigid rules of positive law, the severity of which had to be mitigated in order to do justice. In general, this contrast has no parallel in the development of international law; the legal concept of equity is a general principle directly applicable as law.

Furthermore, in the Fisheries Jurisdiction case, (ICJ Reports 1984) the ICJ insists that states have an obligation to take account of the rights of other states. The ICJ decided that "the fundamental rule of general international law governing maritime delimitation... requires that the delimitation line be established while applying equitable criteria to that operation, with a view to reaching an equitable result."

Article 6 of the UNWC elaborates on how to implement equitable and reasonable utilization. Riparian states are obliged to weigh all relevant factors and circumstances at the outset in order to assure compliance with the principle of equitable and reasonable utilization. The factors listed in Article 6 are not exhaustive, that means it could include joint bodies, third parties and technical commissions without giving priority to any current factor over others since one of them could be more important in certain cases. In fact, many factors should be considered in allocating water entitlements including climate, population, existing hydrology uses, economic and social needs (Majzoub et al. 2012).

Meanwhile, Article 6(2) foresees the possibility of communication between the riparian states in many situations, when the natural conditions lead to a decrease in the quality of waters of the watercourse (Alistair Rieu-Clarke et al. 2012). 
However, Majzoub et al. (2012) argue that conflict remain between watercourse states on what should be given to each factor concerning Article 6(3). In the same way, there are significant endeavors, such as the Legal Assessment Model (LAM) prepared by the Center for Water Law, Policy and Science IHP-HELP. LAM is useful in identifying, evaluating and measuring the related factors to equitable and reasonable use (Wouters 2005). As such, disputing states can refer to LAM to weigh the relevant factors of Article 6.

In the case where the quantity or quality of water is not sufficient to meet the current needs of the riparian states, the principle of equitable and reasonable utilization considers two steps, one of which is to check if the relevant uses are reasonable. The second step requires the competing reasonable uses to be rearranged based on equity. If the upstream state works on a new project or program to increase the flow diversion to its irrigation or electricity, that would have adverse impacts on the water flows downstream. However, the latter should also take the necessary actions to update its irrigation system and invest in drip irrigation systems. Ultimately, the question of whether the current use is reasonable depends on various lines of arguments. The requirements of "reasonableness" does not meet with the most economical use. Nevertheless, riparian states need to follow a win-win approach by considering related factors to reach the concerned principle to prevent any frictions (Mohammed Helal 2007).

\section{CONCLUSION}

In light of the conventional nature of the UNWC and regardless of its customary roots, it has limited scope to its parties and they could be subjected to any damage due to use of the international watercourse. Nevertheless, the UNWC provides an important rule that a watercourse becomes an international watercourse if it is situated in more than one state. To date, international community has adopted the principle of equitable and reasonable utilization as an obligation under the UNWC or part of customary law. That principle holds a unique feature as it is generally accepted by the upstream and downstream states at least in their official statements. The international jurisdiction has approved that direction through the ICJ's judgments in the Gabcikovo-Nagymaros Project case and the Pulp Mills case. Still, the application challenges are hindering the states' own interpretation according to their interests especially the upstream states. Despite this, the respective states are under obligation to respect that principle completely with good faith and implement it on mutual cooperation. They should cooperate in data sharing and refrain themselves from implementing any planned measures without consent of the notified states. States will then have a common goal to attain optimal utilization and adequate protection of the shared watercourses.

\section{ACKNOWLEDGEMENT}

The authors would like to thank the Universiti Kebangsaan Malaysia for supporting this study through grant code GUP-2018-067.

\section{REFERENCES}

Alistair Rieu-Clarke et al. 2012. UN Watercourses Convention User's Guide. Dundee: IHP-HELP Centre for Water Law, Policy and Science.

Aaron, W. T. 1998. Conflict and cooperation along international waterways. Water Policy 249(1). p. 156.

Chelkeba, A. 2017. Notification and consultation of projects in transboundary water resources. Mizan Law Review 11(1) p.129.

Donaldson, J.W. 2011.Paradox of the moving boundary: Legal heredity of river accretion and avulsion. Water Alternatives 4(2): 155

Jolly, S. 2018. A legal analysis of linking human right approach to access to water and sharing of trans-boundary rivers in South Asia. In Shifting Horizons of Public International Law, edited by J. Kaul et al. New Delhi: Springer.

Loures, F. et al. 2015. Everything You Need to Know About the UN Watercourses Convention. World Wildlife Fund.

Majzoub, T. et al. 2012. Contribution to the operationalization of the principle of equitable and reasonable utilization of international watercourses through jurimetrics. The Law of International Responsibility 373 (65): 383.

Mechlem, K. 2009. Moving ahead in protecting freshwater resources: The ILC draft articles on transboundary aquifers. Leiden Journal of International Law 22: 801.

Mohammed Helal, S. 20017. Sharing Blue Gold: The 1997 UN Convention on the Law of non- navigational Uses of International Watercourses Ten years on. The Journal of International Environmental Law and Policy 340(18): 347.

McCaffrey, S. 2001. The Law of International Watercourses: Non-Navigational Uses. London: Oxford University Press.

Lema, A. E. 2015. The UN Watercourses Convention from the Ethiopian context: Better to join or stay out. Haramaya Law Revision 4: 11.

Okonkwo, T. 2016. A Glimpse into International Regimes Governing the Use of Transboundary Freshwater Resources. Journal of Law, Policy and Globalization 52(10) p. 13.

Salman, M. A. 2007. The UN Watercourse Convention ten years later: why has its entry into force proven difficult? Water International 32(1): 14.

Salman, M.A. 2015. Entry in to force of the UN Watercourses Convention: Why should it matter? International Journal of Water Resources Development 4(4): 8. 
Soboka, T. 2008. Between ambivalence and necessity: Occlusions on the path towards a basin wide treaty in the Nile Basin. Colorado Journal of International Environmental Law and Policy 20(3): 291.

Schwebel, S. 1982. Third Report on the Law of Non-navigational Uses of International watercourses, UN Doc. A/CN.4/348, 1982, Yearbook of the ILC, Vol. 2, Part 2.

Tanzi, A. 1997. Codifying the minimum standards of the law of international watercourses: remarks on Article one and a half. Natural Resources Forum 21(2): 116.

Vick, J. M. 2012. The law of international waters: Reasonable utilization. Chicago-Kent, Journal of International and Comparative Law 141(12): 146.

Utton, A. 1996. Which rule should prevail in international water disputes: That of reasonableness or that of no-harm? Natural Resources Journal 36: 638.

Wouters, P. 1999. The legal response to international water conflicts: The UN Watercourses Convention and Beyond. German Year Book of International Law 293(42): 316.

Wouters, P. et al. 20015. Sharing Transboundary Waters an Integrated Assessment of Equitable Entitlement: The Legal Assessment Model. UNESCO.
Zawahri, A. N. et al. 2011. Fragmented governance of international rivers: Negotiating bilateral versus multilateral treaties. International Studies Quarterly 55: 835.

Saad Abbas Kadhim Alsaadi

Faculty of Law

Universiti Kebangsaan Malaysia

43600 Bangi, Selangor

Email: saadalsaadi@gmail.com

Rasyikah Md. Khalid

Faculty of Law

Universiti Kebangsaan Malaysia

43600 Bangi, Selangor

Email: rasyikah@ukm.edu.my

Wan Siti Adibah Wan Dahalan

Faculty of Law

Universiti Kebangsaan Malaysia

43600 Bangi, Selangor

Email: wsa@ukm.edu.my 